\title{
A NOTE ON THE GENUS PELECINUS.1
}

\section{By Charles T. Brues.}

The peculiar hymenopterous genus Pelecinus is represented in North America by $P$. polyturator Drury, which extends also into South America. Over the southern part of its range, this species varies greatly in color and a number of species have been described from tropical America which are perhaps only variations not worthy of specific rank. ${ }^{2}$ Pelecinus is highly dimorphic and the sexes can be instantly recognized by the form of the abdomen. In the male, this part of the body is strongly clavate and less than twice as long as the remainder of the body, whereas in the female the abdomen is linear and fully five times as long as the head and thorax together. The female of this insect is a common North American insect, and has been bred from the larvæ of scarabæid beetles of the genus Phyllophaga (=Lachnosterna). The male on the other hand is very rarely seen and is always regarded by those familiar with the species as a very unusual find. Since the female is frequently seen in great numbers, there can be no question that the male is actually very scarce and that practically all the individuals of the species in the United States are females. It would seem therefore that these females must ordinarily reproduce parthenogenetically and that under such circumstances female progeny are produced; i.e., that they represent a thelytokous race. On the other hand, among the neotropical color varieties males are well represented in the population for they are frequently obtained by collectors. This makes it probable that the economy of the tropical forms is widely different from that of the nearctic ones.

Ashmead $^{3}$ makes the statement that the female is not rare in some of our northern states during August and September

${ }^{1}$ Contribution from the Entomological Laboratory of the Bussey Institution, Harvard University, No. 302.

${ }^{2}$ Cf. Roman, Ent. Tidskr., 1910, p. 196. I am inclined to believe, however, that there is more than one neotropical species since two males that $I$ have seen show a great difference in the form of the first abdominal segment, exactly as figured by De Romand nearly a century ago. (Mag. Zool., 1842, pl. 86).

${ }^{3}$ Journ. New York Entom. Soc., vol. 10, p. 243, 1902. 
(most of the specimens I have seen bear the date of August; a few July and September )where the female forms a conspicuous object when flying, since its flight is slow and difficult on account of its abnormally lengthened abdomen. He says further, "The male, on the contrary, is extremely rare and exceedingly rapid in flight. It is sharp-eyed, takes flight rapidly, and is rarely captured." I have never seen but one male alive, but it was captured without difficulty. One morning in mid-August 1900, I spied a male resting on the soil beneath an old apple tree on the grounds of the Marine Biological Laboratory at Woods Hole, Mass. It was in company with a considerable number of females and was still there when I returned after hastily securing an insect net from the near-by laboratory building. This male appeared to be in no way especially wary, and although he may have been freshly emerged, he was fully mature, with the body completely colored and hardened. ${ }^{4}$

Judging from the behavior of this individual and the frequency with which males are taken in Central and South America, it seems plausible to suppose that males of the northern race are not nearly so abundant and that this is a true spanandrous race. Probably, however, even in northern localities males at times occur in somewhat greater numbers.

The males are so notoriously uncommon and so prized by collectors that attempts have been made to attract them by enclosing a number of females in a gauze box exposed in a place where the species is abundant. I have been told by collectors in Chicago many years ago that this method is sometimes successful and that in certain localities a few males may be obtained in this way, just as males of certain moths may be trapped in great numbers by the same subterfuge. This may be due to the presence of males only in certain restricted places. At any rate the economy of this extremely aberrant and interesting group of $\mathrm{Hy}-$ menoptera deserves further study, since it appears that in different parts of its geographical range, it very evidently reproproduces in a different manner, the northern race represented

${ }^{4}$ Professor Nathan Banks confirms this observation as he tells me that a male specimen which he took at Falls Church, Va. was likewise not a very active insect. 
almost entirely by thelytokous females and the tropical forms by a comparatively equal proportion of males and females.

The systematic position of Pelecinus has always been a matter of disagreement among hymenopterists. Ordinarily it has been regarded as a highly modified member of the superfamily Serphoidea (Proctotrypoidea), but recently Handlirsch has considered it to form a superfamily annectant between the Terebrantia and Aculeata. Considering its highly specialized form and isolated position it is impossible to determine the relationships of Pelecinus with any great degree of satisfaction. Some recent studies which I have made upon the fauna of the Baltic amber lead me to believe that the recent Pelecinus has been derived from a type represented by the very primitive Stephanidæ through types existent in the early Tertiary that I am inclined to believe show a derivation of Pelecinus from a Stephanid-like ancestor.

Such being the case we have in Pelecinus a primitive type which has become modified in certain regions to a thelytokous method of reproduction, such as is seen in certain very much less primitive parasitic Hymenoptera of the superfamily Ichneumonoidea. In most of these, arrhenotoky prevails although a few cases of thelytoky have been observed and frequently normal arrhenotoky with the occasional production of a very few females in the brood. Evidently the appearance of thelytoky in Pelecinus is definitely related to climate and may be regarded as a recent acquisition.

In $1894^{5}$ Patton described a second North American species from Tennessee to which he gave the name of $P$. brunneipes. This he distinguishes from $P$. polyturator by its smaller size, lighter legs, the presence of an oblong brown cloud in the first cubital cell behind the stigmal cloud, the presence of punctoreticulate sculpture on the disc of the propodeum in place of the transversely arcuately rugose sculpture of $P$. polyturator. I have had in my collection for a number of years a very small female Pelecinus taken by Prof. W. M. Wheeler at Colebrook, Conn., in August 1910, which is probably the form described by Patton. It differs very markedly from all of the numerous females of $P$.

•(Amer. Naturalist, vol. 28, p. 896). 
polyturator with which I have compared it, but no further examples have come into my hands during the eighteen years that have elapsed since this one was obtained. There are however, in the collection of the Museum of Comparative Zoölogy four additional females, three from the Banks collection taken at Falls Church, Va., taken during August and September and one from Jones Creek, Lee Co., Virginia. From Patton's description, the Connecticut specimen differs slightly in having the white antennal annulus restricted almost entirely to the apex of the ninth segment, not extending over the tenth, and in having only a single cloud, mainly in the radial cell of the fore wing.

$P$. brunneipes can hardly be regarded as more than a distinct subspecies, but it is distinguishable very readily from the typical form. The following dichotomy indicates the structural differences between the females of the two.

Front coarsely reticulate medially, smooth at the sides, with some coarse punctures between the reticulate and smooth parts; parapsidal furrows coarsely crenulated or crossstriated; propodeum behind middle distinctly transversely rugose-reticulate, sometimes with large punctures intermixed; fore wing distinctly clouded only in the radial cell; length 50-60 mm.

P. polyturator Drury.

Front between the base of antennæ and the ocelli coarsely and quite regularly punctate, some of the punctures confluent; parapsidal furrows indicated by a line of fine, evenly spaced punctures; propodeum smooth, except for a few separate punctures medially behind the middle; fore wing sometimes (in the type) with a second apical cloud in the cubital area, below the cloud in the radial cell; $;$ length $27-31 \mathrm{~mm}$.

P. polyturator, subsp. brunneipes Patton.

The male of this form must be comparatively rare also as none has ever been recorded and there is no reason to suppose that it occurs any more abundantly than that of the larger North American form.

${ }^{6}$ A variety from Peru, $P$. polyturator, var. apicalis Roman has the ape $\mathrm{x}$ of the fore wing broadly and distinctly blackened. 
Although I have been pondering over the peculiar disparity in the sex ratio of Pelecinus for some years, it is only after having read Vandel's recent paper on geographical parthenogensis ${ }^{7}$ that the significance of the matter seems clear. Vandel applies this term to a condition which he finds to exist in very diverse groups of invertebrates, where two races of a single species occur in different regions, the one reproducing bisexually and the other by a process of permanent parthenogenesis. Furthermore in the cases studied by Vandel, he found that the bisexual race is the one inhabiting the tropical part, or at least the warmer portion of the range of the species. There is also a further difference in the number of chromosomes whereby a condition of polyploidy is developed in the parthenogenetic form.

It is quite evident that the case of Pelecinus agrees exactly with Vandel's cases of geographical parthenogenesis. The tropical forms are bisexual, and quite generally smaller in size, while the northern one is highly spanandrous and the female is extremely large. The large size of the northern race is especially noteworthy as it is a very large insect, particularly the female which may quite probably be a tetraploid form, although this has not been determined cytologically.

Pelecinus is therefore most probably a further example of geographical parthenogenesis and extends the occurrence of the phenomenon to the parasitic Hymenoptera.

${ }^{7} \mathrm{La}$ Parthonegenése géographique, Bull., Biol. France et Belgique, vol. 42 , pp. $166-281 ; 1928$. 

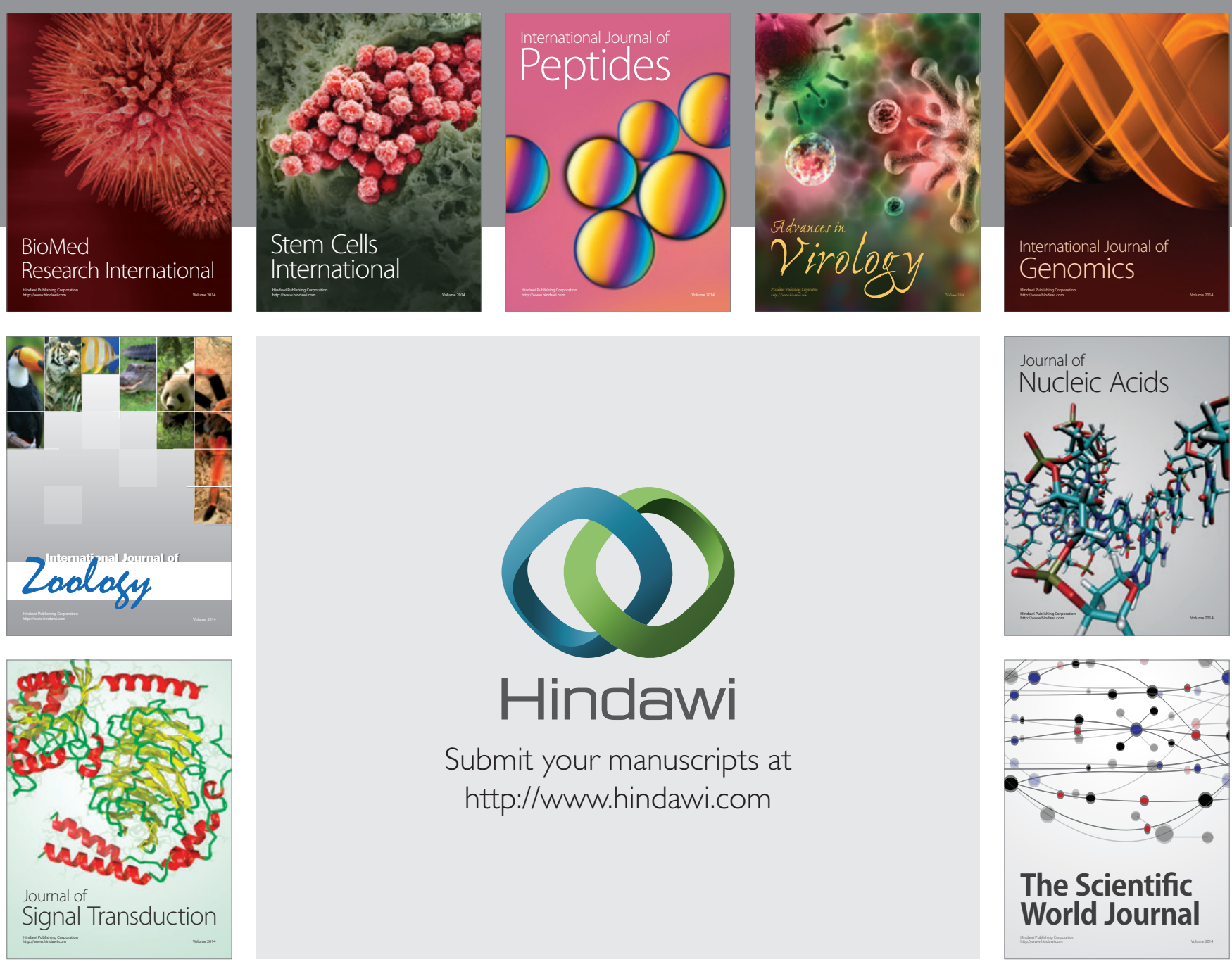

Submit your manuscripts at

http://www.hindawi.com
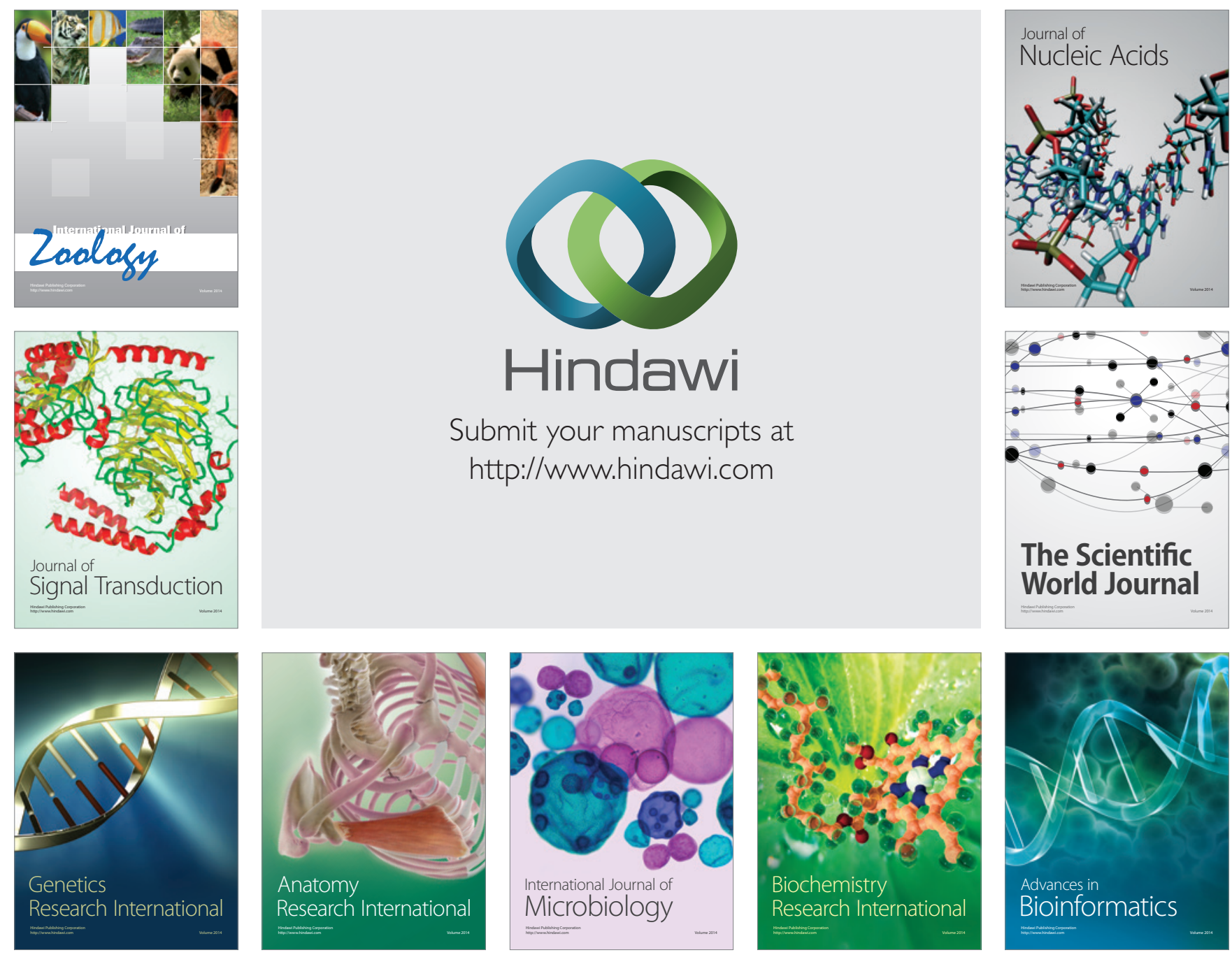

The Scientific World Journal
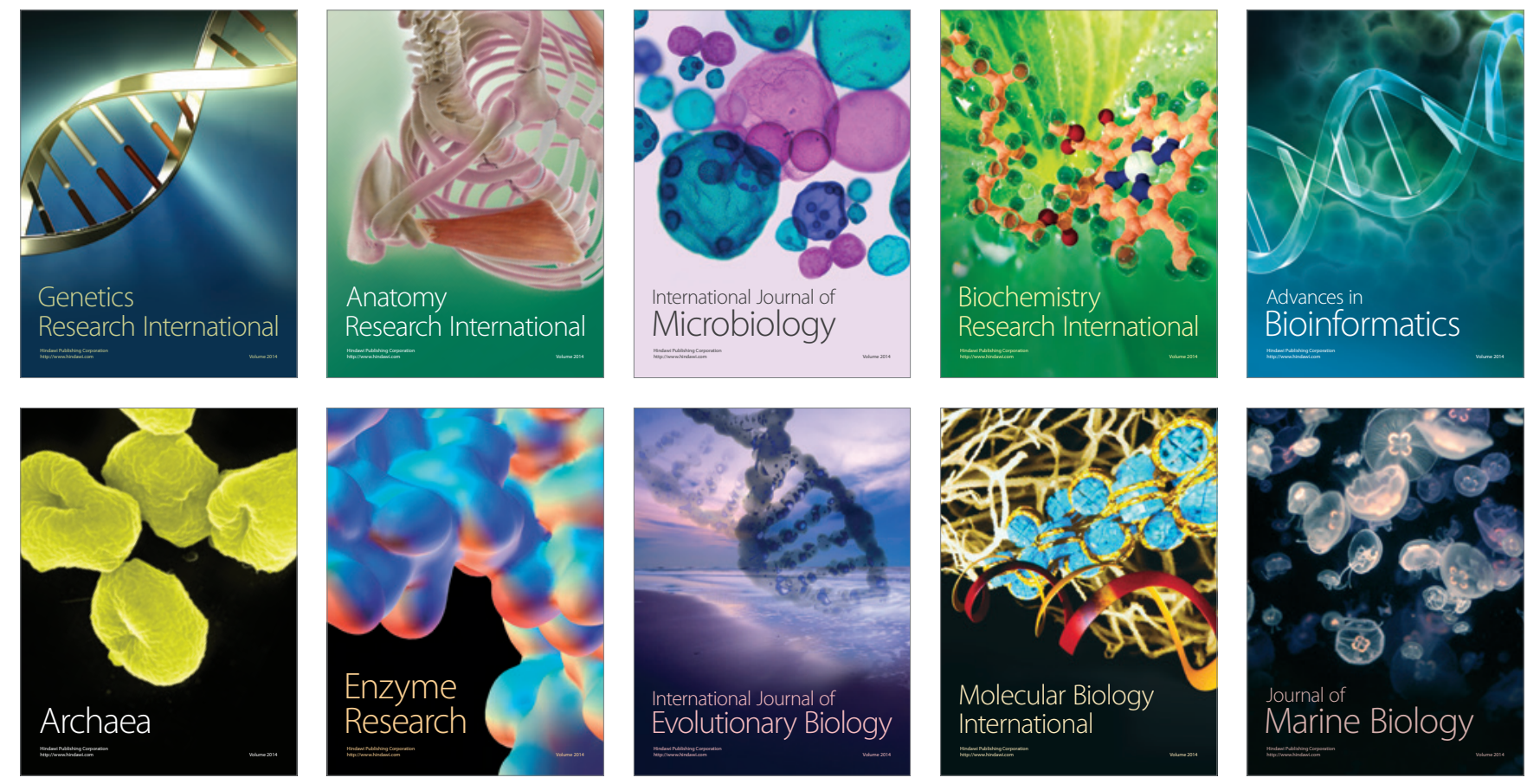